\title{
Urban trees as social triggers: The case of the Ginkgo biloba specimen in Tallinn, Estonia
}

\author{
Riin Magnus \\ Department of Semiotics \\ University of Tartu \\ Jakobi 2, 51005 Tartu, Estonia \\ e-mail: Riin.Magnus@ut.ee \\ Heldur Sander \\ Mahtra 9-121 \\ 20038 Tallinn, Estonia \\ e-mail: heldsander@gmail.com
}

\begin{abstract}
Urban trees are considered to be essential and integral to urban environments, to contribute to the biodiversity of cities as well as to the well-being of their inhabitants. In addition, urban trees may also serve as living memorials, helping to remember major social eruptions and to cement continuity with the past, but also as social disruptors that can induce clashes between different ideals of culture. In this paper, we focus on a specific case, a Ginkgo biloba specimen growing at Süda Street in the centre of Tallinn, in order to demonstrate how the shifts in the meaning attributed to a non-human organism can shape cultural memory and underlie social confrontations. Integrating an ecosemiotic approach to human-non-human interactions with Juri Lotman's approach to cultural memory and cultural space, we point out how non-human organisms can delimit cultural space at different times and how the ideal of culture is shaped by different ways of incorporating or other species in the human cultural ideal or excluding them from it.
\end{abstract}

Keywords: urban greenery; cultural memory; human-plant interactions; Ginkgo biloba; cultural space

In the environmental humanities' endeavour to highlight the role of other species in the shaping of human culture and environments, animals have played the lead role for a long time. However, in the past decades the entangled interactions of 
plants and humans have become the focus of more extensive discussions, evoking what some authors have called a 'plant-turn' (Lewis-Jones 2016). Among plants, trees hold a special place. Trees, sometimes referred to as 'charismatic megaflora' (Hall et al. 2011), are particularly susceptible to imaginative social and cultural constructions (Rival 1998; Cloke, Pawson 2008). Cultural geographers Owain Jones and Paul Cloke have even advocated the mutual entanglement of trees and culture as 'arbori-culture' (Jones, Cloke 2002: 74).

In particular, the special status of trees as cultural mnemonic devices has been noted. This function is related to their aliveness, which is similar to humans', and to their immobility, which aligns them with landscapes (Bloch 1998), as well as their status as living entities spanning many human generations (Davies 1988). However, the recent works on 'plant blindness' (e.g., Wandersee, Schussler 1999) seem to contradict such accounts of the cultural significance of trees, maintaining that due to the specifics of human sensory physiology as well as cultural reasons, people often tend to underemphasize or neglect plants in comparison with animals. The bias of zoocentrism in turn bears direct consequences for the success or failure of plant conservation (Balding, Williams 2016). However, those conclusions were drawn on the basis of observations of Western populations and education systems.

In this paper we will argue that the above-mentioned generalizations about the universal significance as well as insignificance of trees are often too farfetched and lack temporal dimensions. A historical perspective on the cultural interpretations of other species covers phases of remembering and forgetting, of identification and antagonism, which endow the species with different meanings in different times and contexts. Yet the very fact of the presence of other species in human environments will trigger and enhance certain tendencies in cultural memory and identity building. On the one hand, the meanings attributed to other species guide their maintenance and control by humans and hence either favour their existence or not. On the other hand, the activity and transformation of nonhuman species in human-influenced environments often serves as a cause for a shift or for maintaining certain cultural meaning complexes.

The mutual activation of human and non-human semiotic processes and characteristics is central for an ecosemiotic approach to human-environment relations (see Maran, Kull 2014), which we use as a departure point along with an environmental historical perspective. In addition, the Tartu-Moscow School of Semiotics has highlighted the dynamics of forgetting and remembering as the ultimate grounds for any kind of meaning generation, which is reflected also in their notion of 'cultural memory' (Lotman 2013a[1986], 2013b[1985]; Lotman et al. 1978[1971]). However, non-human species as the triggers and mediums 
of cultural memory have not been included in those discussions, although in principle they are not denied such a role either. In the past decades, cultural geographers, historians and landscape researchers have begun to introduce nonhuman agents into memory studies, with trees holding a prominent place as living memorials (Cloke, Pawson 2008) and mnemonic agents (Williams 2014) and as a significant part of the landscapes of remembrance (Gough 2000). These studies mostly focus on the deliberate acts of commemoration and memorization and do not touch upon the acquisition of significance, which happens through social processes that extend beyond mere deliberation and conscious planning. As 'cultural memory' cannot be causally derived from individual and deliberate memorization, but rather refers to the more ephemeral and unplanned dynamics of remembering and forgetting related to cultural texts, the concept might be of use in understanding how trees or other non-human organisms become triggers of social processes.

In the following, we will focus on one case in order to demonstrate how the shifts in the meaning of one particular tree - a maidenhair tree, Ginkgo biloba, specimen growing in at Süda Street in central Tallinn (Fig. 1) - have influenced cultural memory and social confrontations, while paying attention to the characteristics of the specimen and species that have contributed to the rise of this tree to the status of a non-human social actor. Due to the evolutionary and taxonomic specificity of Ginkgo biloba (see next chapter), the species has been extensively studied in paleobotany, biochemistry, dendrology and biogeography; works covering its historical and cultural dimension (e.g., Crane 2013; Unseld 1998) exist as well. In Estonia, previous works have covered the dendrological history of the species in Estonia and the neighbouring countries as well the origins of the Tallinn Süda Street specimen and its rediscovery in the 1930s (e.g., Sander et al. 1990; Sander 1993a, 1999; Sander, Meikar 1994a, b). This work extends beyond the previous studies by adding a focus to the changes of signification as related to changes in the object of signification as well as the incorporation of other species into the building of cultural memory and segregation and integration of social groups. 


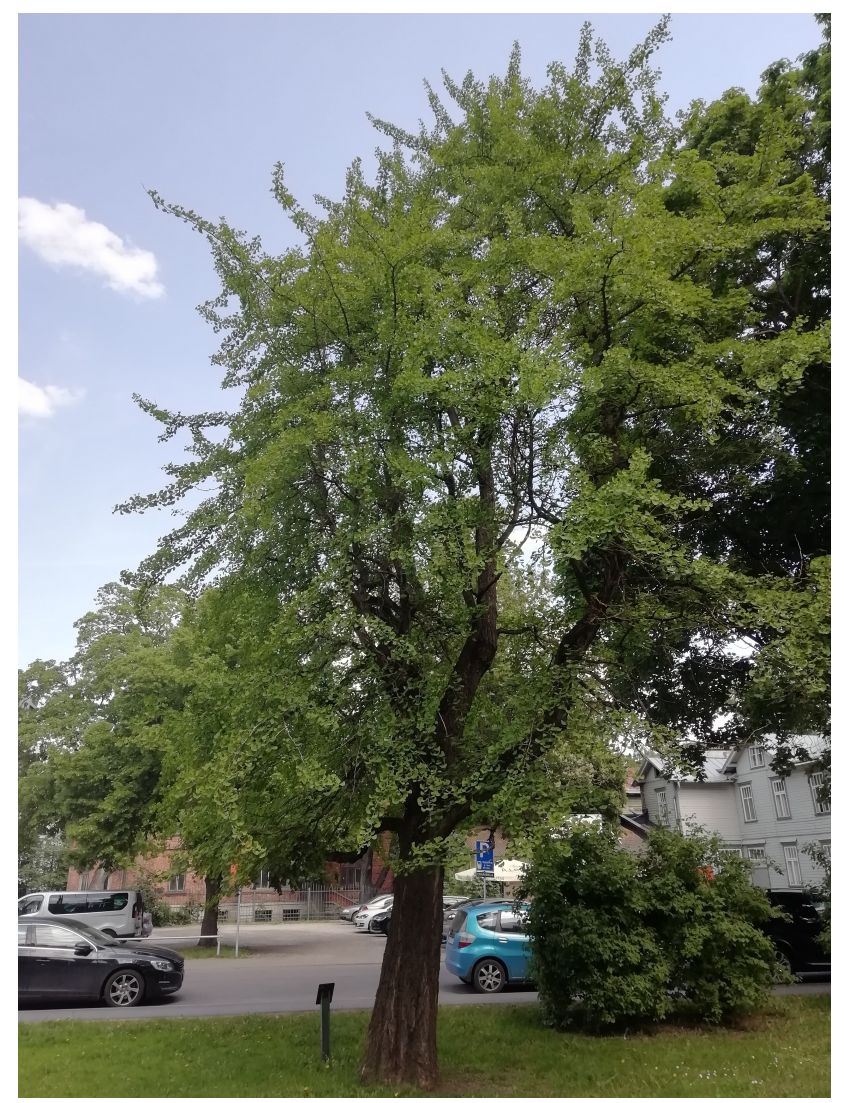

Figure 1. The Süda Street ginkgo tree in Tallinn in June 2019. In December 2018 the height of the tree was $13 \mathrm{~m}$ and its diameter at breast height $60 \mathrm{~cm}$.

\section{Species attributes and the cultural significance of non-human beings}

Although theoretically it is possible to differentiate between the cultural significance of a species and of a specimen belonging to a concrete species, in reality the two are intermingled in the attribution of cultural value to certain non-human subjects. Encounters with concrete specimen shape the image of the whole species, even if the encounters have taken place in unusual or unnatural conditions (zoos, gardens, urban environments) and the typical behavioural repertoire of the species has therefore not been exhibited. On the other hand, the value (and extraordinariness) of one specimen is assessed on the basis of the knowledge and image of the species to which it belongs. Yet the transitions between the evaluation 
of the species and the specimen might not always be smooth and unambiguous, but may instead entail tensions and contradictory grounds of evaluation. For example, McMillen et al. have shown how the meaning a Callery pear (Pyrus calleryana) acquired through surviving the $9 / 11$ terror attack came into conflict with the ecological meaning of the species (McMillen et al. 2018). People would like to grow the saplings from the seeds of this survivor tree to commemorate the tragedy, but due to the invasive nature of the species it is forbidden to spread it.

The Ginkgo biloba tree growing in Süda Street in Tallinn serves as a good illustration of the influence of the knowledge about the species' evolutionary history on the cultural significance of a concrete specimen. Ginkgo biloba is globally known as a living fossil due to its evolutionary age as well as taxonomic rarity. Gymnosperms (Gymnospermae), including Ginkgoales, were widespread in the Mesozoic era in different continents (Hsieh 1992). In Late-Triassic and Jurassic, about 150-200 million years ago, Ginkgoales grew from China to Germany, from Southern America to Australia (Gong et al. 2008; Hsieh 1992; Sander et al. 1990). At the end of Tertiary and in the beginning of Quaternary time, when the climate turned colder and ice covered huge land masses, the Ginkgoales disappeared from Europe, and also from most of Asia (Hsieh 1992). Today, Ginkgo biloba is the only surviving species of the Ginkgoaceae family.

For a long time ginkgo trees were thought to have survived only in conditions associated with humans without any relict natural habitats (cf. Zhao et al. 2010; del Tredici et al. 1992). Even when the presence of a relict populations in the Tian Mu Shan mountains of China was confirmed, it was not clear whether the origin of the trees was natural or whether they had managed to grow there with human assistance (del Tredici et al. 1992). As the trees often grow in the vicinity of Buddhist monasteries, the monks may have planted the trees, although it may also be that the temples were built in majestic locations and the monks restrained from destroying the surrounding environment (del Tredici et al. 1992; Isah 2015). The studies according to which the populations of Chinese ginkgo trees are natural also contain hints at cultural reasons for their preservation. For example, a study which concludes that the population of ginkgo trees in the Chinese Dalou mountains is of natural origin mentions that the indigenous Gelao people abstain from cutting and planting the trees, as this is thought to have unwanted consequences for human fertility and wealth (Tang et al. 2012). Also the Han Chinese, who arrived in these regions in the 17th century have abstained from cutting the ginkgo trees growing in their surroundings (Tang et al. 2012).

The presentation of the evolutionary history of the species displays a "survivor" narrative, the central question of which is whether the species has been able to survive on its own or whether it has survived with the help of human inteventions 
only. If the "independent surviving" of the species appears to be of central importance to its evaluation from an evolutionary stance, we will next see how the cultivation of individuals of the species allows to delimit cultural space and highlight the cultural endeavours in the introduction of other species. Thus somewhat contradictory, yet mutually enforcing ideals of human-nature relations that the species and specimen carry can be noticed here - the former allows to lay stress on the human-independent existence of nature, while the latter brings forth the human as the caretaker and skilled cultivator of non-human nature.

\section{Cultivation and the delimitation of cultural space}

The significance of certain species and specimen in a particular place is also shaped by humans' attempts to push the limits of nature further via cultivation while highlighting their status as cultural beings. The latter entails both skills and knowledge of overcoming the physical limits set to certain species by their natural environment and "enriching" the naturally given local environment with the exotic and the extraordinary. At the same time, cultural contacts and shared cultural space might guide the preferences and adoption of certain species as worth of cultivation, while denying such a status to other species.

In the 19th century, the gardeners mostly came to Estonia and Livonia from Germany (Plath 2012: 50-52; Sander et al. 2014; Pūka et al. 2010: 31-49) and hence the ideas of what could be planted in the Baltics and what not were brought along from Central Europe. At that time, horticulture was "both a representation of power and social engagement" (Plath 2012: 47). Through Germany, the Baltic tree nurseries were also linked with the global network of trade. The seeds and plants brought along from expeditions might also have enriched the sortiment of tree nurseries, at least of those belonging to the manor houses. However, the introduced plants needed special acclimatization conditions and care, and sometimes still did not survive in the novel environment.

The shared composition of cultivated species might further augment the feeling of a shared identity and belonging to the same community. Geographical and climatic closeness enhances the possibilities for the transmission and application of knowledge about other species and might thus ease colonialist endeavours by the introduction of other species (Crosby 1972). Such conditions obviously ease and increase transactions between neighbours, although similarity in natural conditions might also raise the issue of the necessity of distinguishing oneself in cultural terms, the cultivated species offering a good possibility for that. 
The history of the introduction and cultivation of the Süda Street ginkgo tree in Tallinn exhibits the diverse delimitations of cultural space in different eras. Having been brought to Tallinn by a German forester at the end of the 19th century, the ginkgo tree maintained a connection with German culture in the memory of the introducer as well as in the gardening culture of Estonian and Livonian towns. In the 1930s an Estonian scholar of dendrology rediscovered the tree as a dendrological rarity and it was highlighted as being of special value in urban greenery. In the 1960s, the tree was taken under protection as part of the more extensive endeavour to protect individual urban trees. In the following, we will discuss in more detail the different epochs and the corresponding shifts in the delimitation of cultural space that the meanings of the tree reveal. In line with the Tartu-Moscow School of Semiotics, cultural space is understood here not as equivalent to a territorial range, but "as an area of identification found in cultural self-descriptions" and "the spatial organisation of a self-model as well as of the image of the world" (Remm 2015: 67). Yet as an ecosemiotic stance is incorporated as well, the cultural space can be connected with the distribution range of other species, the latter serving as a material ground for the delimitation of the cultural domain of self and the other.

Ginkgo trees were first introduced into Europe from China and Japan in the first half of the 18th century, with the first tree planted in Holland in 1730, after which the trees were planted all over Europe (Zhao et al. 2010); they are extensively used also in modern urban greenery. In the Baltic provinces, the first record of a Ginkgo biloba stems from the year 1800 concerning a tree in the Alūksne (in German Marienburg) castle garden (Schmidt 1800: XI). The fact that the ginkgo specimen was growing there was no surprise, as at that time the garden contained a remarkable number of rarities. The Alüksne ginkgo trees were followed by Estonian ones - the first record stems from the University of Tartu botanical gardens in 1833 (cf. Sander et al. 1990: 9), followed by the tree nurseries of Tallinn as well as the city bastions and private gardens. Although the ginkgo tree was one of the rare species that was grown in manor gardens and tree nurseries of Livonia and Estonia, it must have been well known to the gardeners at that time.

The second half of the 18th century was the time of the rise and flourishing of gardening and tree schools in the Baltic provinces of Tsarist Russia and the beauty of the Baltic urban gardens was mentioned at the end of the 18th century (Hupel 1791: 135-136). After the Great Northern War (1700-1721), Estonia and Livonia were under the rule of Russia, yet the nobility which was comprised of Baltic Germans maintained their status and were responsible also for the major developments in greenery, gardening and creation of parks. The economic development in the peaceful times and the special status of the region in Tsarist 
Russia [the so-called Baltic Special Order (Balti erikord)] along with some specifics in the legal system contributed to the spread and expansion of gardening and the import and introduction of rare species in the manor parks and tree nurseries (Hein 2007: 33-50).

The Estonian capital Tallinn played a special role in the introduction of alien species and gardening in the second half of the 19th century. Gardens and gardening had been an integral part of Tallinn urban life already since the 14th and 15th centuries (Pabst 1870; Üprus 1976). Now, several tree nurseries were established or expanded their activity, the greening of the former bastion areas was undertaken after they were handed over to civilian use after the Crimean War (Kenkmaa, Vilbaste 1965), and the Estonian Gardening Association (Estländischer Gartenbauverein zu Revaler) was established in Tallinn in 1861. At the exhibition of the Association in 1862 various rare plant species were introduced, among them also Ginkgo biloba (Toll et al. 1863: 12-14). According to one version, the Ginkgo biloba specimen growing in Süda Street was brought to Estonia from Germany in the 1880s by the head forester of Tallinn Wilhelm Kühnert (1819-1891). According to another version, the tree was planted in the garden by Heinrich Kühnert (1848-1904), the son of Wilhelm Kühnert and the father of the architect Ernst Kühnert (Kühnert 1930). ${ }^{1}$ Cultivation of exotic plants had become popular in Germany at the beginning of the 19th century and also Wilhelm Kühnert had a great interest in the cultivation of exotic plants (Sander, Meikar 1994b: 230). Kühnert planted the ginkgo tree in his garden in central Tallinn. The garden was one of the biggest and most unique gardens in Tallinn at the time and was also called a Garden of Eden, as it contained fruit trees and ornamental trees besides other plants. ${ }^{2}$ Interestingly, the ornamental garden was arranged following a geographical principle - different regions of the world were to be represented by plants originating from those regions (Kühnert 1953; cf. Sander, Meikar 1994a: 353-355, 1994b: 234, 1995: 56-65), turning the garden into a small model of the world (Fig. 2). By the time Kühnert moved to Tallinn and created his garden in the 1860s, there were already several private gardens in Tallinn with collections of exotic plants (Sander, Meikar 1994b: 233). The district where Kühnert created his garden, was especially remarkable for its large gardens and greenery, drawing several intellectuals to live there at the end of the 19th century (Nerman 2004).

1 The tree was moved to its present location in 1913 due to street construction.

2 In the vicinity of the garden of Kühnert also a tree nursery had been established in 1782 (RA.EAA.30.1.27486; Sander 2004: 95; Varul et al. 2018: 188, 192). 


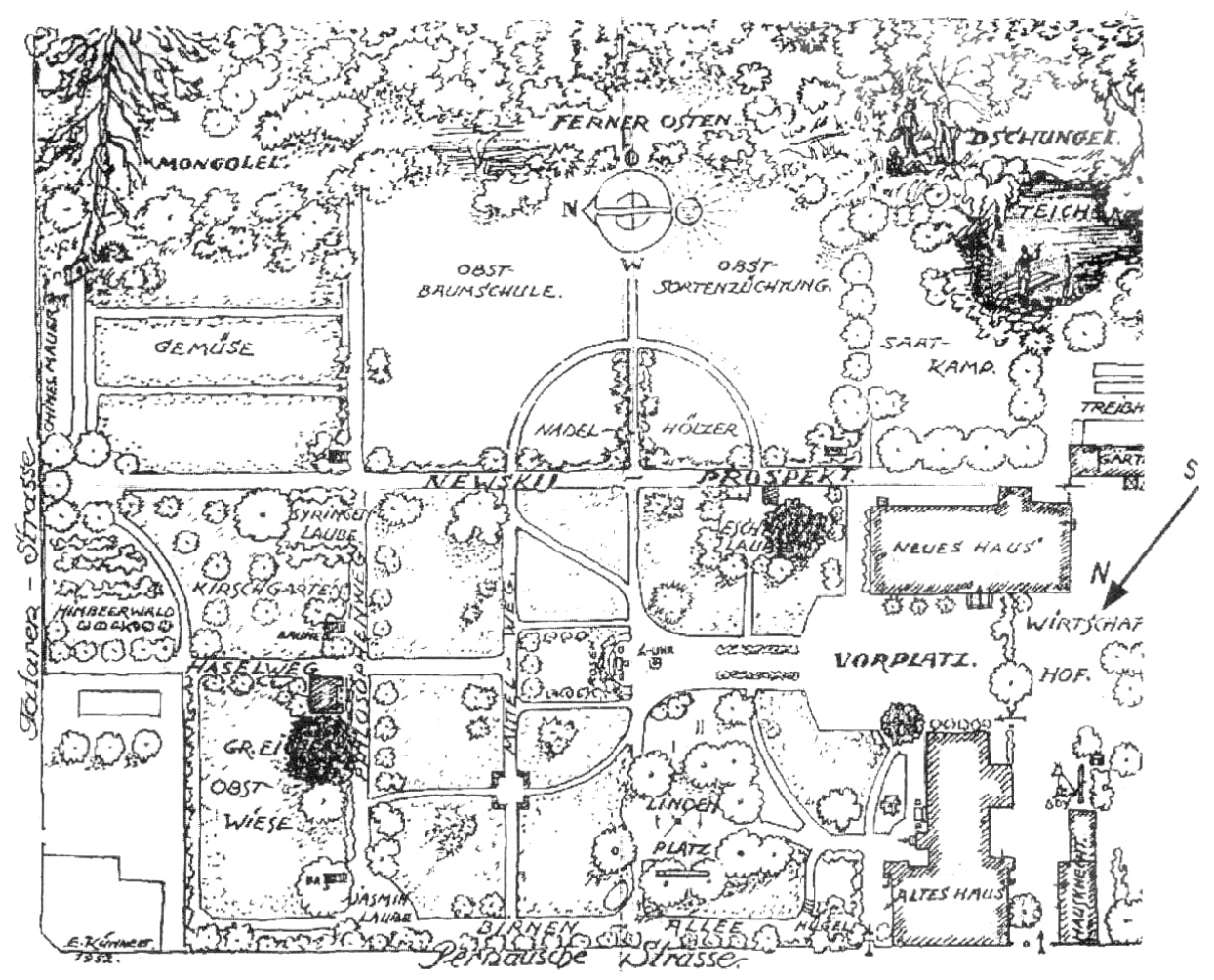

Figure 2. The plan of Wilhelm Kühnert's garden as drawn by his grandson Ernst Kühnert (Kühnert 1953).

The ginkgo tree that Kühnert brought to Estonia was not simply an exotic specimen from afar in spacial and temporal terms, but a tree whose significance was associated with German culture and, more particularly, with J. W. Goethe and his time. Peter Crane (2013: 6) has pointed at the significance of the tree in the time of Goethe: "By the time of Goethe, and later in the nineteenth century, ginkgo was widely grown as an unusual and striking tree: a symbol of the East. In just a hundred years, ginkgo returned to many of those places from which it had been extinguished millions of years before". In 1837 Wilhelm Kühnert had picked a leaf from a ginkgo tree growing by Goethe's garden house and made a realistic drawing of it. He showed the drawing to the head of the imperial gardens from St. Petersburg Alexei von Knorring, who was also highly impressed by the presence of the ginkgo tree in Kühnert's garden (Kühnert 1953). The drawing was 
supplemented with the first stanza of Goethe's poem about the ginkgo. ${ }^{3}$ In the 19th century, the ginkgo tree was known as the Goethe tree in Germany (Masing 1986a: 567 ) and the connection with Goethe has made the tree popular in Germany also these days (Crane 2013: 143).

In the first decades of the 20th century the ginkgo seemed to have become almost forgotten in Estonia. There were only three ginkgo trees growing in Tallinn at that time, two of them in the publicly inaccessible private gardens of Kühnert and Sivers, the third one in a park which contained many ornamental trees among which the ginkgo may have remained unnoticed. ${ }^{4}$ But in the 1930s the city government of Tallinn ordered the first dendrological survey of Tallinn from Eduard Viirok, student at the University of Tartu and the first Estonian dendrologist. Largely due to the works of Viirok, the apparently forgotten ginkgo specimen was discovered anew. Viirok wrote several articles in local newspapers about the ginkgo tree and other rare tree species of the capital (Viirok 1929a, 1929b, 1931, 1932). When writing about another ginkgo specimen growing in at Virumägi in central Tallinn, he highlighted the tree's special character (1930: 243-244) in global and evolutionary terms, as well as its taxonomic rarity, and also mentioned its sacred status in China.

At that time, also the value of single urban trees was officially confirmed - in 1938 four trees were taken under protection in the park of Kadriorg in Tallinn -

3 Goethe wrote the poem "Gingo biloba" in 1815 and it was first published in 1819 (Goethe 1977 [1819]):

Dieses Baums Blatt, der von Osten

Meinem Garten anvertraut,

Giebt geheimen Sinn zu kosten,

Wie's den Wissenden erbaut,

Ist es Ein lebendig Wesen,

Das sich in sich selbst getrennt?

Sind es zwei, die sich erlesen,

Daß man sie als Eines kennt?

Solche Frage zu erwidern,

Fand ich wohl den rechten Sinn,

Fühlst du nicht an meinen Liedern,

Daß ich Eins und doppelt bin?

The poem has also been translated into several languages, including Estonian (see Goethe 1986: 567).

4 The measures of the trees were as follows: the ginkgo in the Kühnert garden $-\mathrm{h}$ (height) $=$ $6 \mathrm{~m}$, dbh (diameter at breast hight) $=10 \mathrm{~cm}$; the gingko in Virumäe park $-\mathrm{h}=4 \mathrm{~m}, \mathrm{dbh}=$ $6 \mathrm{~cm}$; the gingko in the garden of Sivers $-\mathrm{h}=1.5 \mathrm{~m}$ (Viirok 1932: 29). 
an elm tree (Ulmus glabra), a lime tree (Tilia cordata) and two oak trees (Quercus robur) named after Peter the Great. Another wave of taking urban trees under protection occurred in 1966, when also the ginkgo specimen (Ginkgo biloba) in Kühnert's garden at 2 Süda Street, the "Kelch lime" (Tilia $\times$ europea) at the Niguliste Lutheran Church and a black poplar (Populus nigra) as a tree connected with Peter the Great at the Kazan Russian Orthodox Church were taken under protection following the new nature protection law of 1959 (Sander 1993: 161162). That was a time of the spread of environmentalist ideas and movements, covering not just areas of wilderness, but also urban environments. The protection of urban nature exposes a shift in the evaluation of the human activity in towns if the exoticism of the 19th-century gardens had appealed to the human aesthetic appreciation and the beauty that the unification of natural elements and human selection and cultivation can bring about was valued, then in the 1960s human activity was rather seen as a potential threat to urban nature, while a stricter line was drawn between the human expansion and the domain of the natural in cities. As for the ginkgo tree, the officially granted protected status would contribute to its rise to the position of a social disruptor a few decades later.

\section{Urban trees as social reconciliators and disruptors}

As mnemonic or social actors, trees can play various roles, two of the seemingly contradictory ones being social reconciliation and initiation of social conflict. Often, urban trees gain the status of reconciliators in the aftermath of a conflict or disruption, whereby urban greening is used to give a new life to the destroyed landscapes, to cover the wounds of war visible in the ruins, to build a new solidarity among the city dwellers (Shimada, Johnston 2013; Cloke, Pawson 2008; Gough 2000). First of all, trees can aid people in remembering the cultural disruption, by helping to maintain a continuity with the past and remember the destruction and the event of devastation. In some occasions, they offer a dimension of commemoration and remembering, which other kinds of memorial objects cannot fulfill. For example, Glenn Moore has noted that the hibaku jumoku trees of peace (several of them being ginkgo trees), which survived the Hiroshima bombing of 1945, serve a purpose, which other memorial monuments lack, adding a connection with the past to the forward-looking narrative (Moore 2017: 118). The other aspect which makes trees as memorial objects special involves the activities of planting and care, which might help to rebuild the community (McMillen $e t$ al. 2017). Keith Tidball has described the tree symbolism and rituals along with the tree planting activities in the post-Katrina New Orleans as contributing to 
the reestablishment of a post-catastrophe community of practice (Tidball 2013). Thirdly, trees offer a continuity not only in temporal, but also in spatial terms. The planting of trees originating from the countries of the soldiers onto graves and battlefields establishes a connection with the far-lying homeland. Homegrown maple seeds were sown on Canadian graves on the Western Front of WWI (Gough 1996: 78), while seeds from trees growing in the cemeteries in France and Belgium were brought to Australian commemorative gardens (Stephens 2009: 137). Sometimes the recognition of the commemorative role of trees can be prolonged and comes after the trees have been recognized due to some other distinguishing characteristics. Judith Stilgenbauer and Joe McBride write how Dresden, which was heavily bombed in WWII, had designated 22 trees as protected natural monuments by 1999, but none of these was chosen as the "survivors of the war" (Stilgenbauer, McBride 2010: 156-157). However, these days marked "survivor trees" of the great bombing can be found in Dresden's Grosser Garten.

Trees can also serve a function contrasting commemoration and establishment of continuation with the past - trees which are planted or start growing on their own may help to forget the destruction and alleviate the trauma by growing over the ruins of war and "dead zones", hence giving a new life and new beginning to the devastated city. In all these cases, trees are not only planted for different purposes, but they acquire different meanings as the cultural memory of the community itself changes. Moreover, trees themselves can actively shape that memory by covering, shadowing, growing over certain places and thereby contributing to the transformation of the material basis of forgetting and remembering.

In addition to being social reconciliators, trees can also serve as social disruptors and polarizers (see e.g., Braverman 2009). The destruction of symbolic trees may cause social uproar, yet this might be related to their monumental value only. Trees become social disruptors in a different sense, when they are valued not only due to their symbolic significance, but due to the value they have as a part of a particular environment. A threat to the particular tree in these cases embodies a threat to the evaluated environment in its totality. Hence, one precondition for trees to become social disruptors in cities is the recognition of urban greenery as essential to urban environment and integral to city life. The embeddedness in urban life allows the trees to "pick up" and embody values and meanings which recognized or separate members of certain communities. However, a tree usually becomes an embodiment of certain values when a threat to those values is felt - the trees might then become the symbolic centres of the polarized society and social segregation.

Heldur Sander and Toivo Meikar (2003, manuscript) have summed up the history of conflicts over urban greenery in Estonia, pointing out that the first disagreements and conflicts date back to the Middle Ages, the time of the early 
development of Estonian towns. They mention that the following centuries brought about conflicts entailing different reasons and interest groups, from the use of resources in forests belonging to towns (e.g., a conflict over the ownership rights of Naissaare Forest in the 17th century and another concerning the recreational vs resource-centred use of Kloostrimetsa Forest at the beginning of the 20th century) to the public right to access urban parks (e.g., Tallinn's Falck Park at the beginning of the 20th century). One such controversy, which earned strong disapproval from the citizens and was still remembered decades later, took place during the Crimean war (1853-1856), when the residential area of Kalamaja in Tallinn was demolished in the fear of the landing of French and English troops. This included the destruction of gardens and the felling of large trees, inducing objections by those affected. In the 19th century, when people moved to towns in higher numbers and faced the hardships of adapting to the new living environment, a new type of controversy arose (Sander, Meikar, manuscript). This was also reflected in the citizens' imprudent behaviour towards urban greenery (Tarand 1984). Their goats were eating the plants, several trees were cut down and destroyed, which points to the difficulties in accepting the function of greenery as a detached ground of appreciation and constituent of well-being, rather than a vital source of living. As a result, the avenues and parks were manned with guards in the summer. However, all those conflicts concerned forests, parks and groups of trees without the highlighting of single specimen among them.

The Ginkgo biloba specimen in Süda Street was drawn into the middle of a social debate and disruptions in the mid-1980s, inducing what has later been called "the ginkgo tree saga". In the 1980s one of the major plans of the city's infrastructural transformations involved the plan to connect the then Lenin Avenue (a street which was aligned with several buildings of institutional and national significance) with Pärnu Maantee, one of the city's central highways. This was parallelled by a plan to build a new opera theatre at the new breakthrough. The search for a suitable place for the opera theatre had been going on already since the 1960s. In the 1970s and 1980s three architectural competitions took place to find a suitable location and architectural solution to the theatre. In the 1970s the theatre was planned to be built at Tõnismägi, a central location in Tallinn. In this connection, the question was raised what to do with the Soviet monument to the liberators of Tallinn ${ }^{5}$ located at Tõnismägi. ${ }^{6}$ The Head Office of Architecture and Planning at the Ministry of Culture of Soviet Estonia suggested keeping the

5 The monument was erected to commemorate the Soviet soldiers who had been buried there in 1945; in 2007 it was removed from the location, inducing protests from the Russianspeaking population of Tallinn.

6 Estonian National Archive: ERA.R-1797.3.1896, 132. 
monument in the same place, although alternative locations to the monument were not denied. ${ }^{7}$ The decades-long search for the location and architectural solution to the theatre and the delay in the start of the building was a source of discontent and created the feeling of an urgent need to continue with the development of Tallinn after the ruptures of WWII. This sentiment was reflected in the words of the former city architect of Tallinn, Dmitri Bruns: "In this way, the most important object, both in terms of its content as well as its importance for city building, has begun to move from one area of the city to another and the realization of such an object important for the national culture has been postponed till an unforeseeable future" (Bruns 1993: 166; our translation, R. M., H. S.).

In the mid-1980s the breakthrough of Lenin Avenue and the building of the opera theatre would have meant the demolition of a district of wooden houses in the middle of Tallinn along with its greenery, a part of which was the $9.4 \mathrm{~m}$ high ginkgo tree. A dendrological survey estimated that 541 trees would face the threat of being cut down in the area of the potential construction works, six of which were estimated to be of such high value that they should be protected with all possible measures. ${ }^{8}$ The area was described as "the most species-rich quarter of central Tallinn" by dendrologists and geographers (Elliku et al. 1985; Elliku, Tarand 1986: 135). The potential threat to the district was addressed via petitions (Tallinna linnakodanike 1998[1987]), public protests, opinions expressed in public media by several intellectuals, biologists and heritage specialists. The petition, titled “The heart of the town needs protection!" (Linna süda vajab 1998[1987]) and signed by 140 persons participating in the 1987 protest, might have been one of the first calls for public democracy in Soviet Estonia. The petition referred to a freshly established Act of the Soviet Union concerning public discussion of significant questions of the state as the legal ground for the right to engage the public in making decisions about cases such as, e.g. the transformation of a district in central Tallinn. Given the time of these events, the mid-1980s, the protests acquired patriotic overtones (at least in later interpretations). Suddenly, a single ginkgo tree was drawn into the centre of all these discussions and confrontations. In public media, biologists were writing about the evolutionary specificity of the tree as well as the value of this concrete specimen as the northernmost specimen of the species ${ }^{9}$ (Masing 1985, 1986b; Kesklinn... 1985), heritage protectors stressed the need to consider the greenery and housing of the area as one integral whole.

\footnotetext{
7 Estonian National Archive: ERA.R-1797.3.1896, 142.

8 Estonian Architecture Museum: EAM.5.1.25. Uurimus Tallinna Süda tänava piirkonna haljastusest; ENSV TA Tallinna botaanikaaed. Tallinn, 1988.

9 These days, there are ginkgo trees which grow even further north.
} 
Those claims were countered by those who held a different opinion, arguing for the necessity of finally getting the building of the opera theatre started.

What was at stake at that time of intense social turmoil in Estonia and struggle for self-determination, was not only the preservation of the tree vs the building of the opera theatre, but the case reveals a wider tension between two ideals of culture. More specifically, the conflict was very much grounded in the question what kind of culture was going to form the essence of the yet-to-become-independent Estonian nation. The nature and heritage protectors saw in the destruction of the old buildings and trees and in the architectural and infrastructural transformations an abrupt break in the continuity with the times preceding the Soviet occupation. Hence, the destruction of the area would have meant a destruction of a material ground of cultural memory. Those favouring the building of the opera house, vice versa, saw in the building of the new opera house the restoration of the broken cultural continuity. As the art historian Leo Gens stated, the war had interrupted the building of central Tallinn and it was now high time to continue with it (Gens 1986). Thus, both parties had their visions of historical continuity, but what one party saw as the continuation of cultural memory, the other saw as a break and vice versa. Secondly, the polarity of high culture vs animistic beliefs was present in a couple of articles pertaining to the case. The polarity was brought about in the writings of those arguing in favour of the new opera house and can be illustrated with a quote from a satirical article written by a school director and well-known Francophile (Leesi 1986: 16; translation R. M.):

Indeed, can't we notice everywhere in the centre of the city renovated trees, which are cemented inside, covered with asphalt and mummified. This, for sure, stems from the animism of our ancestors, from the belief that also trees have to persist until their natural death, until they fall on a passer-by's head.

At a certain point, the editors of the cultural weekly Sirp ja Vasar published a note that they abstain from publishing further satires and other writings on the topic, as they were "drowning" in the piles of such papers (Toimetuselt 1986:16). Those speaking for the preservation of the old district, established a further polarity of pro-nomenclature vs contra-nomenclature activities and also considered the building of the opera theatre in its planned form and location as a deed hostile to culture. The petition of the citizens of Tallinn reads:

We, who have signed this, are convinced that sacrificing at least 227 ancient trees and numerous fruit trees to the pompous Lenin Avenue and to the pompous new opera and ballet theatre with an obviously failed location in Tallinn's Süda Street neighbourhood [...] is extremely hostile to the environment and culture, and also uneconomical. (Tallinna kodanike ...1987) 
In the end, the opera theatre was not built and the tree remains in its place to these days, but it is difficult to determine how much was the final result of debates and how much was due to the turbulent times of the collapse of the Soviet Union. Interestingly, the Kühnert family and their gardens were almost never referred to in those debates of the 1980s (although see Masing 1986a), even though the ground for the milieu value of the area was laid with the 19th-century gardening and housing. The tree had acquired a different context - instead of being a faraway exotic, as it was perceived and presented in the 19th century, it was now part of the local milieu value, encompassing both human constructions and greenery. Moreover, as simultaneously with the "gingko tree saga", Estonia was facing a "Phosphorite War" - protests against starting large-scale phosphorite mining in the North-East of Estonia, the debates surrounding the ginkgo tree were named as "a side battle of the big phosporite war" (Parmasto 1999). The discussions about the value of urban greenery and its role in urban planning were thus part of the parallel rise of environmental consciousness and the quest for self-determination.

As Juri Lotman et al. (1978[1971]: 212) have pointed out, social cataclysms are accompanied by "a sharp increase in the degree of semiotic behavior", which is expressed, for example, in changing of names and representations. It is also accompanied by the search for material grounds for symbols, which would embed the latter in the daily world and provide them with additional credibility. If manmade monuments testify to the will to insert and solidify some event or phenomenon in collective memory, then trees and other living beings that grow or live in certain places allow for grounds of remembrance that are as if already given and hence beyond mere human will. Thus, the human introduction of the Süda Street ginkgo tree was "forgotten" in the debates of the 1980s and its "natural" value stressed, although the tree served the purpose of highlighting the value of a district as a unity of natural and cultural elements.

Even though those involved in the debates stressed that the question did not concern only the preservation of the single ginkgo tree, just like the rebuilding of Lenin Avenue would not have entailed the building of an opera theatre only, the opera theatre and the ginkgo tree formed a pair of symbols already in the 1980s, while the original context was forgotten later. The ginkgo tree has become a part of the active shaping of cultural memory, becoming a living being which carries a special symbolic function. When describing the general properties of cultural memory, Juri Lotman highlights the symbolic function of signs, which he associates with remembering. In the context of cultural memory, Lotman (2013: 1739) considers as symbols the signs "which have the capacity to contain, preserve and reconstruct a memory of the previous contexts". However, observing the aftermath of the ginkgo tree conflict, we can see how a symbol will become 
attached to new contexts, making it possible to forget some of the original ones. The forgetting of the original context (the preservation of the area with high milieu value vs new urban developments) has brought along the transformation of the former polarization into what has become known as the 'ginkgo tree syndrome' in Estonia. The phrase is used when carrying out something of importance is obstructed by something insignificant - the opera theatre being the significant element of culture and the ginkgo tree symbolizing the insignificant phenomenon. The phrase has been used in Estonia in discussions ranging from harbour buildings to the reformation of the whole education system. Recently, the former EU commissioner for transport (2010-2014) and former PM of Estonia (20022003) Siim Kallas revoked the metaphoric pairing of the ginkgo tree and the opera theatre when addressing the opponents of the new Rail Baltic railway project in a radio interview (15.06.2017), saying that the opera theatre was not built at that time due to the opposition of a small group of people, implicitly issuing the warning that the same might happen with the railway project. ${ }^{10}$

Although more than 30 years have passed since the tensions around the ginkgo tree escalated, the tree continues to appear in the phrase 'the ginkgo tree syndrome', which, if we were to seek for the hidden meanings, still marks the persevering tension between the local, the traditional, the small-scale vs the global, the innovative and the large-scale. So, although one significant context of the 1980s has been forgotten, similar confrontations are still present in the current use of the phrase and pinpoint the lines of separation running through the society now and then. As a symbol, 'ginkgo tree' in Estonian refers to the shared memory and understanding of 'normality', which, paradoxically, the symbol itself has been creating.

\section{Conclusion}

The temporal length of each feedback cycle of human and non-human interactions depends on the properties of the organisms as well as social time. In case of mammals, their own activity and behaviour can give rather fast input to their interpretation by humans (see e.g., Maran 2015), but for the immobile trees, which might have a lifespan of several human generations, a different time scale should be used to notice the influence of a species or a specimen on cultural significations. The ginkgo tree was brought to Estonia at the end of the 19th century as an exemplar of a taxonomically and evolutionarily rare species. The tree carried also connotations in terms of the cultural space which it embodied

10 See https://www.err.ee/602343/kallas-loodab-et-rail-balticut-ei-taba-holmikpuujaooperimaja-saatus. 
and symbolized - this particular specimen originated from Germany and was associated with German culture through associations with J. W. von Goethe and his time, but also through the German roots of gardening in the Baltic provinces. When the tree was drawn into the centre of social uproar in the 1980s, it had been "domesticated" as part of the local milieu and cultural memory of Estonians, while the foreign origin of the species and the specimen was pushed to the margins of cultural memory. This demonstrates that changes in cultural memory can go hand in hand with changes in the delimitation of cultural space and vice versa, and non-human organisms which share their living space with humans may acquire a metonymic significance once they are perceived as an integral part of a certain valued environment.

Besides the temporality of the species/organism in question, the character of interspecies contacts depends on the periods of stability and change, pertinent to social time. In times of social turmoil, when cultural identity is under threat and cultural self-reflection is intensified, non-human beings serve as stable ground of memory and function as witnesses of change, establishing a continuation between the past and the future. In comparison with non-living memorials, they are cherished due to their ability to survive and to live on. Yet as the example discussed above demonstrates, they may also induce clashes between different visions of future. The continuity with the past that they allow to establish may be seen as a break instead, entailing processes and objects which are seen as having inhibited the "normal" development of culture. It seems that the presence of non-human species acquires a merely symbolic significance in these cases; however, the question is just as much about the practices of everyday life - whom the inhabitants of the city will encounter daily and how diverse the interspecific interactions in a human-created lifespace will be. ${ }^{11}$

11 Acknowledgements. The research has been supported by the Estonian Research Council grant PUT1363 (Semiotics of multispecies environments: Agencies, meaning making and communication conflicts) and by research grants IUT 2-44 (Semiotic modelling of selfdescription mechanisms: Theory and applications) and PRG314 (Semiotic fitting as a mechanism of biocultural diversity: Instability and sustainability in novel environments) of the Estonian Ministry of Education and Research. 


\section{References}

Balding, Mung; Williams, Kathryn J. H. 2016. Plant blindness and the implications for plant conservation. Conservation Biology 30: 1192-1199.

Bloch, Maurice 1998. Why trees, too, are good to think with: Towards an anthropology of the meaning of life. In: Rival, Laura (ed.), The Social Life of Trees: Anthropological Perspectives on Tree Symbolism. Oxford: Berg, 39-55.

Braverman, Irus 2009. Planted Flags: Trees, Land, and Law in Israel/Palestine. Cambridge: Cambridge University Press.

Bruns, Dmitri 1993. Tallinn linnaehituslik kujunemine. Tallinn: Valgus.

Cloke, Paul; Pawson, Eric 2008. Memorial trees and treescape memories. Environment and Planning D: Society and Space 26: 107-122.

Crane, Peter 2013. Ginkgo. The Tree That Time Forgot. New Haven, London: Yale University Press.

Crosby, Alfred 1972. The Columbian Exchange: Biological and Cultural Consequences of 1492. Westport: Greenwood Press.

Davies, Douglas 1988. The evocative symbolism of trees. In: Cosgrove, Denis; Daniels, Stephen (eds.), The Icononography of Landscape: Essays on the Symbolic Representation, Design and Use of Past Environments. Cambridge: Cambridge University Press, 32-42.

Del Tredici, Peter; Ling, Hsieh; Yang, Guang 1992. The ginkgos of Tian Mu Shan. Conservation Biology 6: 202-209.

Elliku, Jüri; Roht, Urmas; Tarand, Andres 1985. Mitte ainunlt hõlmikpuu. Eesti Loodus 9: 558-264.

Elliku, Jüri; Tarand, Andres 1986. Endiste eeslinnade dendrofloorast. In: Tarand, Andres (ed.), Tallinna taimestik. Tallinn: Valgus, 134-143.

Gens, Leo 1986. Agulipsühholoogia ja Tallinna tulevik. Sirp ja Vasar 17 Jan, 3.

Goethe, Johann Wolfgang von 1977[1819] Gingo biloba. In: Goethe, Johann Wolfgang von, Sämtliche Werke: in 18 Bänden. Bd. 3. Zürich: Artemis-Verlag; München: Deutscher Taschenbuch Verlag, 348.

- 1986[1819] Ginkgo biloba. (Kaalep, Ain, transl.) Eesti Loodus 9: 567.

Gong, Wei; Zeng, Zhen; Chen, Ye-Ye; Chen, Chuan; Qiu, Ying-Xiong; Fu, Cheng-Xin 2008. Glacial refugia of Ginkgo biloba and human impact on its genetic diversity: Evidence from chloroplast DNA. Journal of Integrative Plant Biology 50: 368-374.

Gough, Paul 2000. From heroes' groves to parks of peace: Landscapes of remembrance, protest and peace. Landscape Research 2: 213-228.

- 1996. Conifers and commemoration - the politics and protocol of planting. Landscape Research 21: 73-87.

Hall, C. Michael; James, Michael; Baird, Tim 2011. Forests and trees as charismatic megaflora: Implications for heritage tourism and conservation. Journal of Heritage Tourism 6: 309-323.

Hein, Ants 2007. Aed ja aeg. Piirjooni eesti aiakunsti vanemast ajaloost. In: Luttsepp, Elo (ed.), Eesti pargid. Vol. 1. Tallinn: Keskkonnaministeerium, Muinsuskaitseamet, Varrak, 17-87.

Hsieh, Ling 1992. Origin and distribution of Ginkgo biloba. The Forestry Chronicle 68: 612-613.

Hupel, August W. 1791. Ueber die Gartenliebhaberey in Lief- und Ehstland. Nordische Miscellaneen 27/28: 534-553.

Isah, Tasiu 2015. Rethinking Ginkgo biloba L.: Medicinal uses and conservation. Pharmacognosy Reviews 9: 140-148. 
Jones, Owain; Cloke, Paul 2002. Tree Cultures: The Place of Trees and Trees in Their Place. New York: Berg Publishers.

Kenkmaa, Rudolf; Vilbaste, Gustav 1965. Tallinna bastionid ja haljasalad. Tallinn: Eesti Raamat. Kesklinn...1985. Kesklinn I. Milliseks kujuneb Süda tänava kvartal? Sirp ja Vasar 6 Dec, 12.

Kühnert, Ernst 1930. Haruldased puud Tallinnas/“Imepuu” Viruväravamäel. Vaba Maa 23 Aug, 7.

- 1953. Der Garten Eden. Manuscript (copy in Tallinn City Archive).

Leesi, Lauri 1986. Hõlmikpuu. Sirp ja Vasar 24 Jan, 16.

Lewis-Jones, Kay E. 2016. Introduction. People and plants. Environment and Society 7: 1-7.

Linna süda vajab kaitset! 1998. In: Arme, Lea; Niitsoo, Viktor (eds.), MRP-AEG Infobülletään 1987-1988. Tallinn: SE\&JS, 227-230.

Lotman, Juri 2013a[1986] Kultuurimälu. Akadeemia 10: 1736-1746.

- 2013b[1985] Mälu kulturoloogilises valguses. Akadeemia 10: 1731- 1735.

Lotman, Juri; Uspenski, Boris; Mihaychuk, George 1978[1971] On the semiotic mechanisms of culture. New Literary History 9: 211-232.

Maran, Timo 2015. Emergence of the "howling foxes": A semiotic analysis of initial interpretations of the golden jackal (Canis aureus) in Estonia. Biosemiotics 8: 463-482.

Maran, Timo; Kull, Kalevi 2014. Ecosemiotics: Main principles and current developments. Geografiska Annaler Series B-Human Geography 96: 41-50.

Masing, Viktor 1985. Elusad puud kivises linnas. Eesti Loodus 3: 146-153.

- 1986a. Saurus linnas. Eesti Loodus 9: 564-568.

- 1986b. Hõlmikpuust, Pariisist ja Leesist. Lauri Leesile hõlmikpuu asjus. Sirp ja Vasar 14 Feb, 16.

McMillen, Heather; Campbell, Lindsay K.; Svendsen, Erika S. 2019. Weighing values and risks of beloved invasive species: The case of the survivor tree and conflict management in urban green infrastructure. Urban Forestry \& Urban Greening 40: 44-52.

- 2017. Co-creators of memory, metaphors for resilience, and mechanisms for recovery: Flora in living memorials to 9/11. Journal of Ethnobiology 37: 1-20.

Moore, Glenn 2017. Hibaku jumoku, nature, and Hiroshima's recovery after the A-bomb. In: Lowe, David; Atherton, Cassandra; Miller, Alyson (eds.), The Unfinished Atomic Bomb: Shadows and Reflections. Lexington Books; 117-134.

Nerman, Robert 2004. Süda-Tatari puitasum: haritlaste linnaosa Tallinnas. Tallinn: Tallinna Raamatutrükikoda.

Pabst, Eduard 1870. Der revalsche Rosengarten. Beiträge zur Kunde Ehst-, Liv- und Kurlands, herausgegeben von der Ehstländische Literärischen Geselschaft. Band I, Heft III, 260-276.

Parmasto, Erast 1999. Hõlmikpuu sündroomi sündroom. Sirp 1 Apr, 2.

Plath, Ulrike 2012. Baltic asparagus: Transnational perspectives on gardening and food culture (17th-19th cc.). In: Paškevica, Beata (ed.), Tulkojums ar garšu. Ėdiena valodnieciskie un starpkultūru aspekti. Valmiera: Vidzemes Augstskola, 40-64.

Pūka, Tarass; Zunde, Ruta; Zunde, Ilmars 2010. Latvijas dārznieki no sendienām līdz 20. gadsimta nogalei. Riga: LU Akadēmiskais apgāds.

Remm, Tiit 2015. Sociocultural Space: Spatial Modelling and the Sociocultural World. [PhD thesis.] Tartu: Tartu University Press.

Rival, Laura 1998. Trees, from symbols of life and regeneration to political artefacts. In: Rival, Laura (ed.), The Social Life of Trees: Anthropological Perspectives on Tree Symbolism. Oxford: Berg, 1-36. 
Sander, Heldur 1993a. The ginkgo (Ginkgo biloba L.) in Estonia. Proc. Estonian Acad. Sci. Biol. 42: 264-273.

- 1993b. Conservation of parks, gardens, and trees in Tallinn - An historical review and the present situation. In: Eensaar, Agu; Sander, Heldur (eds.), Planning of Cultural Landscapes: Dedicated to the 275th Anniversary of Kadriorg Park. Tallinn: Tallinn Botanic Garden, 158179.

- 1999. Ginkgo in Estonia and neighbouring countries. International Dendrology Society Yearbook 1998. London: Dendrology Charitable Company, 63-70.

- 2004. Puukoolid. In: Tamm, Jaan (ed.-in-chief) Tallinn: entsüklopeedia. Kd 2, N-Ü. Tallinn: Eesti Entsüklopeediakirjastus, 95.

Sander, Heldur; Elliku, Jüri; Paivel, Aleksei 1990. Hõlmikpuu (Ginkgo biloba L.) Eestis. Tallinn: Eesti Teaduste Akadeemia.

Sander, Heldur; Meikar, Toivo 1994a. Hõlmikpuu meenutab kunagist Eedeni aeda. Eesti Loodus 12: 353-355.

- 1994b. The father and son Kühnerts in the development of forestry and horticulture in Estonia. Proceedings of the Estonian Academy of Sciences, Biology and Ecology 43: 229-239.

- 1995. Igatsus noorusaja paradiisi järele. Kühnertite suguvõsast. Kultuur ja Elu 8: 56-65.

- 2003 About the History of Conflicts over Urban Forestry in Estonian Towns against the Background of European Towns. (manuscript)

Sander, Heldur; Meikar, Toivo; Magowska, Anita 2014. The learned gardeners of the Botanical Gardens of the University of Tartu and their activities (1803-1918). Acta Baltica Historiae et Philosophiae Scientiarum 2: 53-110.

Schmidt, A. 1800. Verzeichniß derjenigen Gewächse, so sich in der Marienburgischen Gartnerey befinden und wovon Doubletten gegen Tausch oder für Bezahlung, wie auch mehrere seltene schöne Saamen zu haben find. Dorpat: M. G. Grenzius.

Shimada, Lia D.; Johnston, Mark 2013. Tracing the troubles through the trees: Conflict and peace in the urban forest of Belfast, Northern Ireland. Journal of War and Culture Studies 6: 40-57.

Stephens, John 2009. Remembrance and commemoration through honour avenues and groves in Western Australia. Landscape Research 34: 125-141.

Stilgenbauer, Judith; McBride, Joe R. 2010. Reconstruction of urban forests in Hamburg and Dresden after World War II. Landscape Journal 29: 144-160.

Tallinna kodanike petitsioon linnasüdame kaitseks 6. detsembril 1987. a. 1998. In: Arme, Lea; Niitsoo, Viktor (eds.), MRP-AEG Infobülletään 1987-1988. Tallinn: SE\&JS, 227.

Tang, Cindy Q.; Yang, Yongchuan; Ohsawa, Masahiko; Yi, Si-Rong; Momohara, Arata; Su, Wen-Hua; Wang, Huan-Chong; Zhang Zhi-Ying; Peng, Ming-Chun; Wu, Zhao-Lu 2012. Evidence for the persistence of wild Ginkgo biloba (Ginkgoaceae) populations in the Dalou Mountains, southwestern China. American Journal of Botany 99: 1408-1414.

Tarand, Andres 1984. Linnarohelusest Tallinna muljetel. Eesti Loodus 8: 499-506.

Tidball, Keith G. 2013. Trees and rebirth: Social-ecological symbols and rituals in the resilience of Post-Katrina New Orleans. In: Tidball, Keith G.; Krasny, Marianne E (eds.), Greening in the Red Zone: Disaster, Resilience and Community Greening. Heidelberg: Springer 257-296.

Toimetuselt. 1986. Sirp ja Vasar 14 Feb, 16.

Toll, E. v.; Ackermann, L.; Hansen, E. v.; Dietrich, A. 1863. Mittheilungen über die Wirksamkeit des Ehstländischen Gartenbau-Vereins zu Reval bis zum October 1862. Hefte 1. Reval, Gedruct bei Lindfors Erben. 
Unseld, Siegfried 1998. Goethe und der Ginkgo: Ein Baum und ein Gedicht. Frankfurt am Main: Insel-Verlag.

Üprus, Helmi 1976. "Kivise linna antipood". Aedadest keskaegses Tallinnas. Ehitus ja Arhitektuur 2: 46-50.

Varul, Liivi; Kask, Silvia-Kristiin; Kiudsoo, Mauri; Maldre, Liina; Mäeorg, Kalmer; Reppo, Monika; Russow, Eerki; Kriiska, Aivar 2018. Archaeological investigations on Tõnismägi 11a and Pärnu Road 44 plots in Tallinn. In: Russow, Erki; Haak, Arvi (eds.), Archaeological Fieldwork in Estonia 2017. Tallinn: Muinsuskaitseamet; Tallinna Ülikooli ajaloo, arheoloogia ja kunstiajaloo keskus; Tartu Ülikooli ajaloo ja arheoloogia instituut, 175-192.

Viirok, Eduard 1929a. Ajaloolisi aedu ja puid Tallinnas. Eesti Mets 10: 241-243.

- 1929b. Pealinna rohelise haruldused. Ring läbi rohelise Tallinna (Botaanilis-dendroloogiline skits). Vaba Maa 6 Oct, 8.

- 1930. Ringkäik Tallinna linna puiestikkudes. Kasvatus 5: 243-248.

- 1931. Tallinna linna puiestikkude ajaloost. Majaomanik. IX, 105-108; 121-126.

- 1932. Ülevaade Tallinna linna puiestikest. Tartu Ülikooli Metsaosakonna toimetised 22: 1-91.

Wandersee, James H.; Schussler, James H. 1999. Preventing plant blindness. The American Biology Teacher 61: 82-86.

Williams, Howard 2014. Antiquity at the National Memorial Arboretum. International Journal of Heritage Studies 20: 393-414.

Zhao, Yunpeng; Paule, Juraj; Fu, Chengxin; Koch, Marcus A. 2010. Out of China: Distribution history of Ginkgo biloba L. Taxon 59: 495-504.

\section{Городские деревья как социальные триггеры: случай с образцом гинкго в Таллинне, Эстония}

Городские деревья считаются важными составляющими городской среды, они способствуют биологическому разнообразию городов, а также благополучию их жителей. Кроме того, городские деревья могут служить живыми памятниками, помогая помнить крупные социальные катаклизмы и укреплять преемственность с прошлым, а также выступать в качестве социальных разрушителей, вызывающих столкновения между различными идеалами культуры. В данной статье мы рассматриваем конкретный случай дерева гинкго, растущего на улице Сюда в центре Таллинна, чтобы продемонстрировать, как изменения в значении нечеловеческого организма могут формировать культурную память и становиться основой социальных конфронтаций. Для этого мы используем экосемиотический подход, интегрированный с подходом Юрия Лотмана к культурной памяти и культурному пространству. Мы показываем, как другие (нечеловеческие) живые организмы очерчивают культурное пространство, могут повлиять на оформление культурной памяти и, теряя свой изначальный контекст, становятся символами и влияют на идеалы культуры. 


\section{Linnapuud kui sotsiaalsed "päästikud": hõlmikpuu (Ginkgo biloba) juhtum Tallinnas}

Puud on tänase linnakeskkonna olulised osad, seda nii linna bioloogilise mitmekesisuse kui linnaelanike heaolu seisukohast. Samas toob kasvav linnastumine kaasa suurema vajaduse elamispindade järele ning ühes sellega sagenevad ka väärtuskonfliktid kohalike elanike ja arendajate vahel. Neil juhtudel on linnapuud sageli sotsiaalsete "päästike" rollis, markeerides ühiskondlikke lõhesid ning eri huvigruppide vastandlikke väärtusi. Hõlmikpuu, mis kasvab Tallinnas Süda tänaval, sattus sääraste ühiskondlike debattide keskmesse 1980. aastate keskel (juhtumit tuntakse ka kui "hõlmikpuu saagat"). Puu toodi Eestisse Saksamaalt 19. sajandi teises pooles osana tollasest saksa mõjutustega aianduskultuurist. Hõlmikpuu kui linna bioloogilise mitmekesisuse väärtusliku elemendi taasavastas 1930. aastatel eesti dendroloog Eduard Viirok ning kaitse alla võeti puu 1960. aastatel. 1980. aastateks oli hõlmikpuu omandanud metonüümiline tähenduse, tähistades haljastust ja miljööväärtust piirkonnas, mida ähvardasid radikaalsed muutused uue ooperiteatri ja tänavaehituse valguses. Tollal käibele tulnud vastandus 'hõlmikpuu vs ooperiteater' märkis ulatuslikumat pinget erinevate kultuuriideaalide vahel - üks osapool nägi muutustes normaalset kultuuriarengut, mille II maailmasõda oli katkestanud, samas kui teine osapool nägi olemasoleva haljastuse ja hoonestuse hävitamises murrangut pidevuses, mis oli püsima jäänud tormilistest aegadest hoolimata. Tänaseni levinud väljend 'hõlmikpuu sündroom', millega märgitakse millegi olulise tegematajätmist tühisel põhjusel, apelleerib ühisele kultuurimälule, mille paradoksaalsel kombel on aga tekitanud seesama sümbol ise. Hõlmikpuu juhtum on ühtlasi hea näide sellest, kuidas teised liigid võivad mõjutada kultuurimälu kujunemist ning muutuda sümboliteks, mis kaotavad oma algse konteksti. See näitab ka, kuidas teised liigid aitavad eri aegadel määratleda kultuuriruumi ja kuidas kultuuriideaali kujundatakse teisi liike kaasates või välistades. 